This is a pre-copyedited, author-produced PDF of an article accepted for publication in the Journal of International Criminal Justice following peer review. The version of record, Hemi Mistry, 'The Paradox of Dissent: Judicial Dissent and the Projects of International Criminal Justice' (2015) 13 Journal of International Criminal Justice 449, is available online at http://jicj.oxfordjournals.org/content/13/3/449.full.pdf+html

\title{
The Paradox of Dissent
}

\section{Judicial Dissent and the Projects of International Criminal Justice}

\author{
Hemi Mistry*
}

\begin{abstract}
Additional opinions - dissenting opinions, separate opinions, declarations, and permutations thereof - are a familiar, if sometimes controversial, aspect of the international jurisprudential landscape. Given that the controversy provoked by additional opinions focuses on their perceived impact on the authority of judgments and decisions of international tribunals, and even the authority of the institutions themselves, additional opinions go to the heart of the manner in, and effectiveness by, which international tribunals discharge their functions. Yet, particularly in the context of international criminal justice, additional opinions have often been overlooked as a subject of critical engagement in their own right. Therefore, the purpose of this article is bring into focus the practice of judicial dissent, that is, the expression of strongly held and fundamental disagreement by judges through the vehicle of the additional opinion, and to stimulate a wider critical engagement with dissentient judicial practice. Rather than providing a review of the orthodox and doctrinal arguments in favour and against the publication of additional opinions, this article offers a reading of five prominent examples of judicial dissent in international criminal law and suggests how this practice could be conceived from the perspective of the functions that international criminal adjudication is expected to serve.
\end{abstract}

\section{Introduction}

Deviance, difference, defiance, dissent. Often uttered in the same breath, each can evoke strong political and sociological connotations. ${ }^{1}$ Expressions of judicial disagreement in the form of dissenting and separate opinions, as well as declarations, are a familiar aspect of the international jurisprudential landscape. Yet, little focus has been directed specifically at the role played by judicial dissent in advancing the projects of international criminal justice and shaping the nature of the justice that the institutions of international criminal justice claim to pursue. ${ }^{2}$ At the same time, international criminal courts and tribunals have been responsible

\footnotetext{
* PhD Candidate, University of Nottingham. The author thanks Dr Louise Arimatsu, Professor Olympia Bekou, Professor Dino Kritsiotis and the two anonymous reviewers for invaluable comments on earlier drafts. All errors are my own.

1 J. Jetten and M.J. Hornsey (eds), Rebels in Groups: Dissent, Deviance, Difference, and Defiance (WileyBlackwell, 2011).

${ }^{2}$ General accounts of the theory and practice of dissent in international criminal courts and tribunals include G. Sluiter, 'Unity and Division in Decision Making — The Law and Practice on Individual Opinions at the ICTY', in B. Swart, A. Zahar and G. Sluiter (eds), The Legacy of the International Criminal Tribunal for the Former Yugoslavia (Oxford University Press, 2011)191; N. Jørgensen and A. Zahar, 'Deliberation, Dissent, Judgment',
} 
for producing some of the most iconic instances of judicial dissent in international law. Justice Radhabinod Pal's dissent at Tokyo, ${ }^{3}$ Judge Christine Van den Wyngaert's Minority Opinion in Katanga before the International Criminal Court (ICC), ${ }^{4}$ the recent series of rhetorically and substantively powerful dissents emanating from the International Criminal Tribunal for the former Yugoslavia (ICTY), ${ }^{5}$ and Judge Hans-Peter Kaul's multiple dissents at the ICC, ${ }^{6}$ have all resonated beyond the relatively enclosed world inhabited by the community of international lawyers - judges, practitioners, and academics.

On a narrow reading, it is possible to criticize dissentient practice because it undermines the perceived authority of the judgment with which it disagrees or even undercuts the standing of the institution responsible for that judgment. ${ }^{7}$ While these criticisms may be valid in their own right, such analysis is too restrictive. Focusing on so-called 'fundamental dissents', namely, those that express a 'judge's strong sentiment about a legal or factual issue, ${ }^{8}$ this article will consider such dissents from a wider, functional perspective. It is suggested that the publication of fundamental dissents, particularly those explicitly challenging the lawfulness of the exercise of judicial power by a court, plays a constructive role in strengthening the legitimacy of those institutions and enhances their capacity to pursue the substantive aspiration of justice. This is the paradox of dissent. ${ }^{9}$ On the one hand, judicial dissent undermines and may even risk frustrating the legitimacy of international criminal courts and tribunals by prompting the various constituencies of international justice to question the correctness of their decisions and judgments. However, precisely by doing so, such dissents ultimately strengthen the legitimacy of those institutions and the aims that they seek to advance.

Before exploring some examples of this paradox in operation, the following section will explain how it operates in principle, paying particular attention to the objectives pursued by international criminal courts and tribunals. It will focus on the need for accountability in the exercise of judicial power and inclusivity in the process of determining when that power is used. In doing so, this section will identify the role that judicial dissent - given the nature of judicial authority in the context of international criminal justice - is able to play in the attainment of these interests.

\section{Dissent and International Criminal Justice}

in G. Sluiter et al. (eds), International Criminal Procedure: Principles and Rules (Oxford University Press, 2013)1151.

${ }^{3}$ Dissenting Judgment of Justice Radhabinod Pal, in R.J. Pritchard (ed.), The Tokyo Major War Crimes Trial, Vols 105-108 (Edwin Mellen Press, 1998) (hereinafter 'The Tokyo Major War Crimes Trial').

${ }^{4}$ Minority Opinion of Judge Christine Van den Wyngaert, Jugement rendu en application de l'article 74 du Statut, Katanga (ICC-01/04-01/07-3436- AnxI), Trial Chamber II, 8 March 2014 (hereinafter 'Minority Opinion of Judge Van den Wyngaert').

${ }^{5}$ Dissenting Opinions of Judge Carmel Agius and Judge Fausto Pocar, Judgment, Gotovina and Markač (IT-0690-A), Appeals Chamber, 16 November 2012 (hereinafter 'Judge Agius' and 'Judge Pocar', respectively).

${ }^{6}$ This article will focus on the Dissenting Opinion of Judge Hans-Peter Kaul, Decision Pursuant to Article 15 of the Rome Statute on the Authorization of an Investigation into the Situation in the Republic of Kenya, Situation in the Republic of Kenya (ICC-01/09-11-Corr), Pre-Trial Chamber II, 31 March 2010 (hereinafter 'Dissenting Opinion of Judge Kaul, Authorization').

${ }^{7}$ Sluiter, supra note 2, at 215-216; Jørgensen and Zahar, supra note 2, at 1186-1187, 1190-1192.

${ }^{8}$ Jørgensen and Zahar, supra note 2, at 1191-1192.

${ }^{9}$ Contrast with Separate Opinion of Judge Fouad Ammoun, Barcelona Traction, Light and Power Company, Limited (Belgium v. Spain), ICJ Reports (1970) 3, at 316. 
It is not the objective of this article to provide a comprehensive account of orthodox debates on the desirability of permitting the publication of additional opinions. ${ }^{10}$ Rather, by offering one account of judicial dissent from the perspective of the advancement of projects of international criminal justice, this article intends to bring into focus the practice of dissent by international criminal judges, a practice often overlooked as a subject of critique in its own right, despite its prevalence. In doing so, it is hoped that this article will encourage a wider enquiry into how this practice affects the manner in which international criminal courts and tribunals discharge their functions. However, to establish the basis on which this article proceeds, it is necessary to briefly outline the contours of the existing debate and consider a handful of preliminary issues.

Typical accounts of attitudes toward the publication of additional opinions in the context of international adjudication focus on the contrasting attitudes that are derived from domestic judicial traditions. Whereas the common law tradition has generally adopted a permissive attitude, civil law jurisdictions are taken to represent a more restrictive one. ${ }^{11} \mathrm{At}$ the heart of this distinction lies the perceived impact the publication of additional opinions has on the authority of a court. Advocates claim that their publication strengthens the court's authority, primarily through the transparency into the judicial procedure that additional opinions engender. However, critics of their publication assert that it risks undermining and frustrating that authority. ${ }^{12}$ These attitudes toward the publication of additional opinions are underpinned by certain assumptions regarding the nature of judicial authority. ${ }^{13}$ Although drawing on domestic law theory in the context of international law is perhaps an inevitable reality, care must be taken when determining what are appropriate transpositions in light of the characteristics of international justice and its institutions. ${ }^{14}$ Therefore, before transposing such assumptions fostered within the context of domestic legal systems to the international context, it is necessary to first determine the nature of judicial authority in the context of international criminal justice. It is only having done so that the appropriateness of such transpositions can be determined and the impact of the publication of dissent on that authority be assessed. ${ }^{15}$

This article proceeds on the basis that international criminal justice does not share those characteristics of hierarchically organized models of judicial authority that demand the observance of a robust interpretation of the principle of secrecy (involving the suppression of additional opinions) in order to preserve that authority. ${ }^{16}$ Rather, international criminal justice,

\footnotetext{
${ }^{10}$ Taken to denote all forms of opinions published in addition to the judgment or decision of a court dissenting and separate opinions and declarations, whether authored individually or jointly. This article is part of a broader doctoral research project that engages in a comprehensive critique of existing perspectives on the practice of publishing additional opinions by international judges in light of the substantive and procedural attributes of international (criminal) justice.

11 See G. Sluiter, 'Separate and Dissenting Opinions', in A. Cassese (ed.), The Oxford Companion to International Criminal Justice (Oxford University Press, 2009) 510, at 511; Sluiter, supra note 2; Jørgensen and Zahar, supra note 2 .

12 F. Jhabvala, The Development and Scope of Individual Opinions in the International Court of Justice (University Microfilms International, 1977); I. Hussain, Dissenting and Separate Opinions at the World Court (Martinus Nijhoff, 1984); R.P. Anand, 'The Role of Individual and Dissenting Opinions in International Adjudication', 15 International and Comparative Law Quarterly (1965) 789; Declaration of President Sir Percy Spender, South West Africa (Liberia v. South Africa; Ethiopia v. South Africa), ICJ Reports (1966) 3, § 20.

${ }_{13}$ M.R. Damaška, The Faces of Justice and State Authority: A Comparative Approach to the Legal Process (Yale University Press, 1986).

${ }^{14}$ Generally, on legal transplantations, see D. Nelken, 'Towards a Sociology of Legal Adaptation', in D. Nelken and J. Feest (eds), Adapting Legal Cultures (Hart Publishing, 2001) 7, at 14.

15 Ibid.

${ }^{16}$ Damaška, supra note 13 , at 19.
} 
like international law more widely, displays closer resemblance to the coordinate, or horizontal, ideal-type of authority, with official authority distributed widely, if unevenly. ${ }^{17}$ In this context, the mechanisms of oversight and accountability for the exercise of judicial authority lie beyond the institution or organization and in the hands of the body politic subject to its decisions. ${ }^{18}$ For example, the dependence of such judicial institutions on their own legitimacy as perceived by states, international organizations, and other actors in order to secure their political support, and technical cooperation and assistance to enable those judicial institutions to carry out their mandate, ${ }^{19}$ all stand in favour of the need for greater transparency in decision-making, rather than secrecy.

Before explaining how transparency — in particular, that provided by the publication of dissent - operates to strengthen judicial authority, it is necessary to address one particular criticism of the principle underlying, and practice of permitting, the publication of additional opinions based on the specific characteristics displayed by criminal justice procedure. Doing so will demonstrate how attitudes in favour of a restrictive approach to the publication of additional opinions are underpinned by more fundamental concerns on the necessity for a robust application of the principle of secrecy. Understood as such, the suppression of minority views forms only one aspect of the implementation of the principle of secrecy, one which would be insufficient to obtain the objectives sought on its own.

The criticism is that the publication of dissenting opinions - particularly those expressing disagreement on findings of fact - alongside judgments pronouncing verdicts of guilt found by a trial chamber beg the question whether the 'beyond reasonable doubt' threshold of proof was, in fact, met by the chamber. ${ }^{20}$ In response, it may be submitted that the issue underlying this concern is not the publication of expressions of judicial disagreement, but rather the quorum of decision-making used by international criminal courts and tribunals to arrive at their verdicts. So long as judgments are determined on the basis of a majority vote - rather than requiring unanimity - knowledge of the fact that one third of the chamber disagreed with the verdict has the same outcome as that foreseen for the publication of dissent. Furthermore, even if the publication of the outcome of the vote was prohibited, knowledge of the possibility that the decision could have been rendered by a majority may give rise to suspicion. Moreover, the suppression of reasoned dissenting opinions deprives actors of the opportunity to determine whether the doubts expressed by the dissenting judge were reasonable or not, which may allow suspicion to fester. As such, the debate regarding the appropriateness of the publication of additional opinions must be considered in the wider procedural context within which they occur.

Accordingly, this article proceeds on the observation that the norm of transparency in proceedings is a better 'fit' for international criminal justice in light of the structure of authority contained therein. From here, it suggests how the actual function of dissentient practice might be understood. Therefore, the focus will not be on the legality of judicial practice according to its conformity with the governing statutes of the respective courts and tribunals. ${ }^{21}$ Rather, this article will suggest how dissentient practice - irrespective of its legality - may strengthen the capacity of international criminal courts and tribunals to pursue

\footnotetext{
${ }^{17}$ Ibid., at 24 et seq.; B. Röling and A. Cassese, The Tokyo Trial and Beyond (Polity Press, 1993), at 29, where Bernard Röling explained how '[i]nternational law functions in quite a different set of relations [to domestic law]: a legal community without a legislator, without a judge, without a central power, a society in which the relations are more horizontal than vertical'.

${ }^{18}$ Damaška, supra note 13, at 24.

${ }^{19}$ See below. But generally, see T.M. Franck, The Power of Legitimacy Among Nations (Oxford University Press, 1990), at 16.

${ }^{20}$ C. Safferling et al., International Criminal Procedure (Oxford University Press, 2012), at 526.

${ }^{21}$ Ibid.; Sluiter, supra note 2; Sluiter, supra note 11.
} 
not only the objectives intended for them by those responsible for the institutions' establishment, but also the broader societal goals that judicial proceedings are perceived to serve. ${ }^{22}$ Before taking this argument further, it is helpful to provide a brief review of the principal objectives attributed to international criminal justice.

\section{A. Objectives of International Criminal Justice: A Review}

International criminal justice is concerned with ensuring accountability for the perpetration of crimes under international law through the investigation and prosecution of individuals. International criminal justice, as one particular 'justice-producing regime', ${ }^{23}$ holds ambitions beyond the formal justice found in the enforcement of international criminal law in accordance with the rule of law. Individuals must be held accountable for crimes they commit in order to 'do' justice. Underlying this commitment to 'doing justice' is the liberal commitment to treat individuals as moral agents; punishment is deserved, and therefore 'just', when individual rational actors bear personal responsibility. ${ }^{24}$ Formal justice, namely, the adherence to the principles of legality and due process are essential characteristics that distinguish the law and legal process from competing forms of politics. ${ }^{25}$ Yet, international criminal justice, whether concerned with establishing the parameters of acceptable conduct (as discussed below) or the imposition of individual responsibility, is inherently concerned with normative questions of 'right' and 'wrong'.

It is possible to identify two further objectives associated with the recourse to international criminal courts and tribunals in the pursuit of international criminal justice. ${ }^{26}$ The retrospective orientation of the enforcement objective should be contrasted with the prospective orientation of another function of international criminal justice, that of norm projection and clarification. Here, the process of holding individuals accountable for violations of international criminal law is thought to contribute to the prevention of future violations of the law by emphasizing the parameters of lawful and legitimate conduct. ${ }^{27}$ Although the effectiveness of the threat of prosecution and punishment as a deterrent to the commission of crimes by future actors can be questioned, ${ }^{28}$ the jurisprudence of international criminal courts and tribunals does clarify the law under which individuals, as rational actors, should conduct their affairs.

Second, proceedings and judgments of international criminal courts and tribunals are often given a pedagogic function. Through the process of investigating a situation, the presentation of that evidence and the rigorous process of cross-examination and judicial analysis, the resulting judgment is often thought to contribute to the establishment of a

\footnotetext{
${ }^{22}$ J.E. Alvarez, 'What are International Judges For? The Main Functions of Adjudication', in C.P.R. Romano, K.J. Alter and Y. Shany (eds), The Oxford Handbook of International Adjudication (Oxford University Press, 2014) 158 , at 160.

${ }^{23}$ K. Clarke, Fictions of Justice: The International Criminal Court and the Challenge of Legal Pluralism in SubSaharan Africa (Cambridge University Press, 2009), at 23-24.

${ }^{24}$ D. Robinson, 'A Cosmopolitan Liberal Account of International Criminal Law', 26 Leiden Journal of International Law (2013) 127, at 132-133. Cf. M. Drumbl, Atrocity, Punishment and International Law (Cambridge University Press, 2007); M. Osiel, Making Sense of Mass Atrocity (Cambridge University Press, 2009), at 18 et seq.

${ }^{25}$ J. Shklar, Legalism (Harvard University Press, 1964).

${ }^{26}$ Other objectives are recognized, such as the maintenance or restoration of international peace and security. See

J. Ohlin, 'Goals of International Criminal Justice and International Criminal Procedure', in G. Sluiter et al., supra note 2,55 , at $56-57$.

${ }^{27}$ Ibid., at 58.

${ }^{28}$ Ibid., at 58-59.
} 
historical record of the violence in the context of which the crimes occurred. ${ }^{29}$ Again, while the appropriateness of the judicial forum to 'write history' has been called into doubt by both courts, ${ }^{30}$ and scholars, ${ }^{31}$ actors do look to the judicial process to give meaning to historical events. $^{32}$

\section{B. Dissent, Legitimacy, and International Criminal Justice}

Recalling the coordinate structure of international criminal justice, wherein official authority - not only judicial authority, but legislative and enforcement authority - is distributed widely among a broad class of participants in the international legal system, the effectiveness by which international criminal tribunals can pursue these functions depends on the degree of legitimacy that they command. One account of legitimacy of international criminal courts and tribunals identifies four conceptions of legitimacy, all of which are required for those institutions to succeed in pursuing their objectives. ${ }^{33}$ Whereas 'consent legitimacy' concerns the degree of acceptance and approval of the institution; 'purposive legitimacy' involves the acceptance and approval of the 'values, principles and goals' that international criminal courts and tribunals operate to advance. ${ }^{34}$ Third, 'universal values legitimacy' provides that even when the values or interests advanced by international criminal courts and tribunals do not coincide with a specific sector of its constituency, such values are based on those of the whole community. ${ }^{35}$ Finally, 'performance legitimacy' focuses on issues including the transparency of decision-making and accountability of an institution to its founding authority and constituency. ${ }^{36}$

The expressive potential of dissent can help to strengthen the claim of international criminal courts and tribunals to all four forms of legitimacy by engaging a wider range of actors on whose consent and values these bodies claim to be operating and by holding the exercise of judicial authority accountable to those actors. Given the accepted effectiveness of the criminal justice process in the pursuit of conceptions of social ordering, ${ }^{37}$ along with the high degree of semantic authority of international criminal courts and tribunals, ${ }^{38}$ accountability for the exercise of such authority and power vested in the formal process of criminal adjudication is necessary to limit the risk of its abuse. This is achieved primarily through the operation of dissent as a mechanism of accountability through the transparency into internal deliberative processes.

From the perspective of performance legitimacy, individual judges, through their dissents, open up the process of criminal adjudication to scrutiny and reveal latent interests or influences, to the extent these exist. In turn, this can (or should) prompt subsequent redress -

\footnotetext{
${ }^{29}$ M.R. Damaška, 'What is the Point of International Criminal Justice?', 83 Chicago-Kent Law Review (2008) 330 , at 343; Ohlin, supra note 26, at 62-63.

${ }^{30}$ The ICTY Trial Chamber has described such a function as an 'exercise in futility'. See, Judgment, Delalić et al. (IT-96-21-T), Trial Chamber, 16 November 1998, § 89.

${ }^{31}$ W. Ashby-Wilson, Writing History in International Criminal Trials (Cambridge University Press, 2011); Ohlin, supra note 26, at 62-63.

${ }^{32}$ See below, Section 3.

33 A. Cassese, 'The Legitimacy of International Criminal Tribunals and Current Prospects of International Criminal Justice', 25 Leiden Journal of International Law (LJIL) (2012) 491, at 492-493.

${ }^{34}$ Ibid., at 492.

${ }^{35}$ Ibid.

${ }^{36}$ Ibid., at 493.

${ }^{37}$ F. Pakes, Comparative Criminal Justice (2nd edn., Willan Publishing, 2010); S. Cohen, Visions of Social Control (Polity Press, 1985).

${ }^{38}$ Namely, the strong capacity held by international criminal courts and tribunals to 'shape meanings as well as the ability to establish its communications as authoritative reference points in legal [and it is submitted, political] discourse'. See I. Venzke, How Interpretation Makes International Law (Oxford University Press, 2012 ), at 63.
} 
review of the judgment in appellate proceedings, correction of the law in subsequent cases, or where necessary, institutional reform. By ensuring and demonstrating that institutions and processes of international criminal justice are used independently, impartially, and fairly (the distinguishing characteristics of the judicial process), ${ }^{39}$ dissent can encourage greater acceptance of, and engagement with, these processes and institutions. In turn, this will strengthen claims to 'consent legitimacy' and enhance the effectiveness of the judicial process in ensuring accountability and projecting norms as well as validating and strengthening the project's claims to universality.

Rather than simply holding the exercise of judicial power accountable to only the 'legal community', judicial dissent can hold it accountable to a wider range of audiences by making judicial reasoning accessible to lay audiences. The rhetorical force of the idea of dissent, with its powerful political and social capital, provides an opportunity. The attention attracted by the drama or spectacle associated with dissent provides international judges with a platform to engage directly with social and political actors in a way that may not be possible, even desirable, in the judgment handed down by the court. This way, judicial dissent constitutes a 'portal by which the previously excluded can enter, engage with, and destabilize dominant (or majority) legal discourse'. ${ }^{40}$

From the perspective of international criminal justice and the advancement of the legitimacy of international criminal courts and tribunals, such rhetorically powerful dissent is important for the following reasons. Judicial dissent can become a mechanism of ownership, making real the claim that the project represents a convergence of universal values and thereby enhance claims to 'purposive' and 'universal values' legitimacy. The adoption of procedural models at the ICTY to facilitate greater party participation has been justified in light of the degree of distrust held by defendants and their supporters against the institution. ${ }^{41}$ However, such distrust is not only held by the accused; it is also held by states - whether situation states or third states - whose cooperation and assistance is relied on for the functioning of the judicial process. Not only does the publication of dissent demonstrate the independence and impartiality (or indeed, suggest otherwise) of individual judges, ${ }^{42}$ but by providing an insight into the views of minority judges, dissent empowers minority defendants and other actors whom distrust the exercise of official authority by chambers of international criminal bodies. ${ }^{43}$ For example, utilizing the semantic authority of an individual judge, the dissenting opinion provides a platform for voicing a more diverse range of views on de lege ferenda, stimulating debates within the wider international lawmaking community whether those views should be acted on, while at the same time, constituting a source of arguments that may be pursued by litigants in appellate proceedings in the same case or subsequent cases.

\footnotetext{
${ }^{39}$ S. Roach, 'Justice of the Peace? Future Challenges and Prospects for a Cosmopolitan Court', in S. Roach (ed.), Governance, Order and the International Criminal Court (Oxford University Press, 2009) 225, at 229; Cassese supra note 33 , at 498 .

${ }^{40}$ L. Gunier, 'Demosprudence Through Dissent', 122 Harvard Law Review (2008-2009) 4, at 26.

${ }^{41}$ N.A. Combs, 'Legitimizing International Criminal Justice', 22 Michigan Journal of International Law (20112012) 321, at 326.

${ }^{42}$ Judges of the ICC have recently unanimously and resoundingly endorsed their entitlement to publish additional opinions, describing them as 'a bastion of judicial independence' when rejecting the argument that the views expressed in Katanga by Judge Van den Wyngaert constituted bias which precluded her participation in the subsequent reparation phase of proceedings. See Minority Opinion of Judge Van den Wyngaert, discussed in Section 3(B). See Decision of the Plenary of Judges on the Application of the Legal Representative for Victims for the Disqualification of Judge Christine Van den Wyngaert from the case of The Prosecutor $v$ Germain Katanga, Katanga (ICC-01/04-01/07-3504-Anx), Plenary, 22 July 2014, § 51 (hereinafter 'ICC Plenary Decision').

${ }^{43}$ Ibid.
} 
More specifically, dissent reminds us to reflect on whether the law administered by international criminal courts and tribunals commands 'purposive legitimacy'; does the law reflect the normative foundations of international criminal justice? For example, individual judges have used their right to dissent to open questions to the wider public regarding what justice means from the perspective of the individuals prosecuted by international criminal courts and tribunals. Recently, disagreement between judges has appeared most frequently and often, most forcefully - in the context of ascertaining and applying the law regarding modes of liability. Judgments handed down by the ICTY and ICC demonstrate that international judges have been most divided when determining in what circumstances an individual is personally and criminally responsible for widespread acts of grave criminality which they may not have participated in directly or explicitly ordered. ${ }^{44}$ As the norm of international justice and accountability strengthens with the regularization of investigations and prosecutions of individuals for international crimes, these prominent dissents have played an important role in bringing to a wider audience fundamental debate on who should be held criminally responsible and on what basis.

Finally, by opening up judicial reasoning and decision-making to a wider range of audiences - the importance of which has been recognized by international criminal courts and tribunals $-{ }^{45}$ dissent contributes to the more effective dissemination and integration of norms of international justice.

The following sections offer an interpretation of four instances of judicial dissent in order to suggest how dissentient practice has operated to strength the legitimacy of international criminal courts and tribunals, and thus, their ability to pursue the ambitions of international criminal justice. Whereas, it is more common to engage with the Nuremberg precedent, this article shall focus on the Tokyo precedent, and in particular, the precedent established by Justice Pal and his dissenting colleagues at the International Military Tribunal for the Far East (Tokyo Tribunal). It will examine the so-called 'dissentient judgment' of Justice Pal, ${ }^{46}$ before turning to recent jurisprudential developments at the ICC that witness judicial dissent being used to similar effect.

\section{Judicial Whistleblowing?}

\section{A. Post Second World War Whistleblowing}

The Tokyo Tribunal occupies a conflicted position in the consciousness of advocates of international justice. On the one hand, along with its sister tribunal - the International Military Tribunal at Nuremberg, it forms a landmark in international criminal justice. Its judgment found all 25 Class ' $A$ ' defendants guilty of at least one count of crimes ranging from crimes against peace, war crimes to crimes against humanity, in respect of acts

\footnotetext{
${ }^{44}$ For example, at the ICTY, see Joint Separate Opinion of Judges Theodor Meron and Carmel Agius, Partially Dissenting Opinion of Judge Liu Daqun, Separate Opinion of Judge Arlette Ramaroson, Judgment, Perišić (IT04-81-A), Appeals Chamber, 28 February 2013; Dissenting Opinion of Judge Michèle Picard, Judgment, Stanišič and Simatović (IT-03-69-T), Trial Chamber, 30 May 2013; Partially Dissenting Opinion and Declaration of Judge Liu Daqun, Dissenting Opinion of Judge Bakhtiyar Tuzmukhamedov, Judgment, Šainović et al. (IT-0587-A), Appeals Chamber, 23 January 2014; Dissenting Opinion of Judge Bakhtiyar Tuzmukhamedov, Judgment, Đorđević (IT-05-87/1-A), Appeals Chamber, 27 January 2014. At the ICC, see Minority Opinion of Judge Van den Wyngaert.

${ }^{45}$ Judgment, Sesay, Kallon and Gbao (SCSL-04-15-T), Trial Chamber, 2 March 2009, § 478.

${ }^{46}$ Strikingly, Justice Pal's dissenting opinion, along with that of Justice Henri Bernard, was labelled as a 'dissenting judgment'. See Dissenting Judgment of Justice Henri Bernard and Dissenting Judgment of Justice Radhabinod Pal, in The Tokyo Major War Crimes Trial, Vol. 105.
} 
committed between January 1928 and September 1945, during the course of Imperial Japanese expansionism and later the Pacific War. Yet, despite this cultivation of an image of the 'biggest trial in history', ${ }^{47}$ the Tokyo Tribunal has existed in relative obscurity, even among specialists in international criminal law. ${ }^{48}$ Along with well reported procedural defects, ${ }^{49}$ the main critique of the judgment centres on the idea of 'victor's justice', the notion that the Allies turned to the judicial model in order to reinforce a particular post-conflict narrative of Japanese war guilt and Allied innocence. ${ }^{50}$ Exacerbated by charges of prosecutorial selectivity over which conduct and individuals were prosecuted, ${ }^{51}$ attitudes towards the Tokyo proceedings among even the most ardent supporters of international criminal justice have been, at best, ambivalent.

The Tokyo proceedings stand as a prime example of what has been described as the 'legitimation function of war crimes trials'. ${ }^{52}$ Proceedings of international criminal courts and tribunals provide an official historical narrative 'in which good and evil are clearly defined', and in doing so, they 'exculpate the culture which tries the criminal'. ${ }^{53}$ On the one hand, if the aim of the international criminal justice project is to determine the boundaries of legitimate conduct, then this function of proceedings appears a natural consequence by delegitimizing individuals infringing the law and legitimizing those acting to uphold it. The issue, however, lies in the question: in whose favour is the power of judicial decision-making deployed and in favour of which systems of power? Judicial dissent can operate as, what has been termed, a 'dissident narrative'. In other words, a 'necessary antidote to the official version of the trial', which can undermine the legitimation function of the trial process. ${ }^{54} \mathrm{On}$ this basis, the right to dissent constitutes a powerful internal mechanism of accountability for the exercise of judicial power. ${ }^{55}$ The Tokyo proceedings held its own dissident narrative - the so-called dissenting 'judgment' of Justice Pal. ${ }^{56}$

Justice Pal's 1,235 page dissenting judgment became the bible for critics of the 'victor's justice' embodied by the Tribunal's majority judgment by reason of the comprehensive challenge it presented to its dominant narrative of Japanese war guilt and

\footnotetext{
${ }^{47}$ Röling and Cassese, supra note 17 , at 20.

${ }^{48}$ N. Boister and R. Cryer, The Tokyo International Military Tribunal: A Reappraisal (Oxford University Press, 2008); M. Futamura, War Crimes Tribunals and Transitional Justice: The Tokyo Trial and the Nuremburg Legacy (Routledge, 2008), at 8; F. Hisakazu, 'The Tokyo Trial: Humanity's Justice v Victors' Justice', in Y. Tanaka, T. McCormack and G. Simpson (eds), Beyond Victor's Justice? The Tokyo War Crimes Trial Revisited (Martinus Nijhoff, 2011) 3, at 3-5.

${ }^{49}$ Dissenting Opinion of Justice Henri Bernard, The Tokyo Major War Crimes Trial, Vol. 105, at 18-23; Röling and Cassese, supra note 17, at 50-55; M.C. Bassiouni, 'Nuremberg Forty Years After', 80 American Society of International Law Proceedings (1986) 59, at 64.

${ }^{50}$ R.H. Minear, Victor's Justice: The Tokyo War Crimes Trials (Princeton University Press, 1971); E.S. Kopelman, 'Ideology and International Law: The Dissent of the Indian Justice at the Tokyo War Crimes Trial', 23 New York University Journal of International Law and Policy (1990-1991) 373, at 432-435; Hisakazu, supra note 48.

${ }^{51}$ See Y. Totani, The Tokyo War Crimes Trial: The Pursuit of Justice in the Wake of World War II (Harvard University Press, 2009), at 247-249.

52 G. Simpson, 'War Crimes: A Critical Introduction', in T. McCormack and G. Simpson, The Law of War Crimes: National and International Approaches (Martinus Nijhoff, 1997) 1, at 23-24; M. Koskenniemi, 'Between Impunity and Show Trials', 6 Max Planck Yearbook of United Nations Law (2002) 1.

${ }^{53}$ Simpson, supra note 52.

${ }^{54}$ Ibid., at 27.

55 Judicial dissent cannot cure, although it may highlight, perceived defects or selectivity in earlier stages of the international criminal justice process, such as prosecutorial selectivity.

${ }^{56}$ Note, there were additional, and perhaps more legally compelling dissents, such as that of Justice B.V.A. Röling, discussed in R. Cryer, 'Röling in Tokyo: A Dignified Dissenter', 8 Journal of International Criminal Justice (JICJ) (2010) 1109.
} 
Allied victimhood. ${ }^{57}$ Justice Pal's conclusion - namely, the acquittal of all 25 defendants of all charges - was accompanied by a dense exposition of his legal and factual findings as well as questioning of the conduct of the Allies themselves. ${ }^{58}$ In sum, the judgment provided a fertile source of ammunition with which to repudiate the Tokyo Tribunal, an act that became synonymous for implying Imperial Japan's innocence (or at least, that it was not any more guilty than other nations) for the breakdown of world order witnessed in the Second World War. ${ }^{59}$ Reaction to the judgment is without precedent. Families of those convicted by the Tokyo Tribunal conducted memorials in his honour on his death, ${ }^{60}$ and a shrine has been erected in his name. ${ }^{61}$ Even more remarkably, Justice Pal's figure has featured as the 'elegant and irreproachable hero ${ }^{62}$ of a mainstream feature film. ${ }^{63}$ All this suggests the exceptional nature of Justice Pal's dissent. To be sure, this level of celebrity should remain exceptional. While it is true that this infamy is largely the product of how his judgment was misappropriated and misrepresented by the nationalist movement, ${ }^{64}$ for the purposes of this article, Justice Pal's judgment is instructive for two principal reasons.

First, it reveals the power of the judicial process and judgment, and specifically, the power of the judicial dissent and its potential as an instrument of accountability. For some, the greatest contribution of Justice Pal to international criminal justice is found in his revelation of the effectiveness of the judicial process as an instrument to advance a particular political interest. ${ }^{65}$ It can only be speculated as to the Tribunal's legacy had Justice Pal and his colleagues not dissented. After all, the Statute of the Tokyo Tribunal did not permit the publication of individual opinions. In practice, they became a reality once Justice Pal declared his intention to write an individual opinion. ${ }^{66}$ However, without the dissident narrative provided by Justice Pal and his dissenting colleagues, ${ }^{67}$ it can be asked whether today we would be less alert to the political dimension to proceedings of international criminal courts and tribunals, and therefore, less rigorous in our critique of them and those who deploy them.

\footnotetext{
57 J. Dower, Ways of Forgetting, Ways of Remembering: Japan in the Modern World (New Press, 2012), at 115; Totani supra note 51, Chapter 9; N. Takeshi, 'Justice Pal (India)', in Tanaka, McCormack and Simpson (eds), supra note 48, 126.

${ }^{58}$ For example, regarding the dropping of the atomic bombs on Hiroshima and Nagasaki by the United States in August 1945, see Dissenting Opinion of Justice Pal, The Tokyo Major War Crimes Trial, Vol. 105, at 137-138.

${ }^{59}$ Dower, supra note 57, at 116.

${ }^{60}$ Futamura, supra note 48 , at 110.

${ }^{61}$ N. Onishi, 'Decades After War Trials, Japan Still Honors a Dissenting Judge', New York Times, 31 August 2007.

${ }^{62}$ Dower, supra note 57, at 289.

${ }^{63}$ Puraidu: Unmei no Toki ('Pride: The Fateful Moment') (1998). See M. Green, 'Film Review: Can Tojo Inspire Modern Japan', 19 SAIS Review (1999) 243, at 244; M. Baskett, The Attractive Empire: Transnational Film Culture in Imperial Japan (University of Hawaii Press, 2008), at 152-153.

64 See Takeshi, supra note 57. However, at the same time, Justice Pal did little to discourage that misrepresentation. See Totani, supra note 51, at 224-229. Indeed, he did not confine his remarks to the Tokyo Tribunal. It has been recalled that on his first post-Tribunal trip to Japan in 1952, he consoled the families of the Class ' $\mathrm{B}$ ' and ' $\mathrm{C}$ ' defendants, shaping the public understanding of the minor trials too. G. Fitzpatrick, 'Australian Military Justice in the Aftermath of the Second World War', in K. Heller and G. Simpson (eds), The Hidden Histories of War Crimes Trials (Oxford University Press, 2013) 327, at 328.

${ }^{65}$ G. Simpson, 'Writing the Tokyo Trial', in Tanaka, McCormack and Simpson (eds), supra note 48, 23 , at 27.

${ }^{66}$ N. Boister and R. Cryer (eds), Documents on the Tokyo International Military Tribunal: Charter, Indictments, Judgments (Oxford University Press, 2008), at xiv. Further, it has been suggested that Justice Pal's nomination to the Tokyo Tribunal was influenced by his apparent disinclination for radicalism and because he had been generally perceived as a non-controversial, centrist judge, who happened to have never penned a dissenting opinion throughout his professional life. See Totani, supra note 51, at 223.

${ }^{67}$ While Justices Pal, Bernard and Röling issued dissenting opinions, Justice Delfin Jaranilla and President of the Tribunal, Justice William Webb, issued separate opinions. See The Tokyo Major War Crimes Trial, Vols 105109.
} 
Could the greatest contribution of Justice Pal's judgment be found in its contribution to the institutional memory of the international judiciary and the legacy of the Tokyo Tribunal? Might the spectre of the individual opinions at Tokyo and the fierce demonstration of the individuality of the judges serve as a potent reminder of the power and potential of judicial dissent, a power that could be invoked should the circumstances require.

Secondly, it has been suggested that the Tokyo trial and Justice Pal's judgment have been at the forefront of shaping the Japanese 'collective memory' of Japanese conduct in the run up to, and during in the course of, the Second World War. Indeed, Justice Pal's judgment and the counter-arguments it generated have provided the 'basic conceptual framework for the study of World War II in Japan today'. ${ }^{68}$ To this effect, dissent that takes a fundamentally different interpretation of the evidence presented to the court may extend the social value of judicial intervention beyond its primary function of prosecuting egregious acts of violence. Such dissents may stimulate a discourse outside the courtroom that may be more conducive to the ends of historical truth seeking than courtroom processes.

Contrast this position with those (including many who support the publication of additional opinions on questions of law) who today criticize the publication of dissent on findings of fact on the basis that the expression of factual disagreement undermines the acceptability of the decision on the part of the accused and their supporters. ${ }^{69}$ Finding expression in Article 83(4) of the ICC Statute, this distinction claims support from the restriction on the publication of minority views on determinations of fact within common law jurisdictions, which are typically accommodate expression of the plurality of views held by official decision-makers. ${ }^{70}$ While knowledge of the unanimity of judges in arriving at their decision may indeed strengthen the persuasive authority of that chamber's decision or judgment, ${ }^{71}$ the desire for - and pursuit of - unanimity should not confused with the creation of a fiction of unanimity through the implementation of a principle of secrecy. As aptly demonstrated by the Tokyo proceedings, given the contentiousness of situations of political violence and mass atrocity concerning international criminal justice, the sustainability of a fiction of unanimity may be questioned as a matter of practice. It is unlikely that a judgment rendered by a court, irrespective of the strength of that reasoning, is going to persuade individuals, communities, and societies of the prevailing correctness of the facts as determined by the court, over their appreciation of the facts - appreciations that formed the basis of conflicts and atrocities. Rather, if views are influenced by determinations of fact by international criminal courts and tribunals, it will be by means of the package embodied by the judgment and its additional opinions, taken together. ${ }^{72}$ However, as reaction to the Tokyo jurisprudence demonstrates, the venue for that pursuit may not be the courtroom and the time for that discourse may be some time after the judicial proceedings have been completed.

To summarize, irrespective of what one makes of his legal analysis and interpretation of the evidence, Justice Pal demonstrated the power of judicial dissent as a constraint on the effectiveness with which the judicial process and judgment can be deployed. Indeed, perhaps the greatest testament to this success may be found in contemporary orthodox critiques of self-proclaimed 'fundamentally' dissenting opinions. ${ }^{73}$ In contrast to those critiques, which view fundamental dissents as a threat, it is submitted that the potential for dissent as a

\footnotetext{
${ }^{68}$ Totani, supra note 51, at 245; Boister and Cryer, supra note 33, at 313-314.

${ }^{69}$ Sluiter, supra note 2, at 198.

${ }^{70}$ Ibid.

${ }^{71}$ See to this effect, Art. 74(3) ICCSt., encourages judges to attempt to seek unanimity where possible.

${ }^{72}$ As Neil Boister and Robert Cryer observe, taken individually, each are partial accounts. See Boister and Cryer, supra note 48 , at 312 .

73 Jørgensen and Zahar, supra note 2, at 1191-1192; Sluiter, supra note 2, at 215-216.
} 
constraint is necessary, given both the actual and perceived risk of abuse of judicial power. Through his dissent, Justice Pal demonstrated the need for an effective mechanism to challenge or undermine the use of judicial power or to 'blow the whistle' on defects in procedure. Of course, the compromise was to open Justice Pal's own actions and opinions up to the same critique as the judgment. ${ }^{74}$ Knowledge that such an internal 'whistleblowing' mechanism exists and has been used to demonstrable effect can strengthen the performance legitimacy of the wider process of international criminal adjudication. This assumes a certain degree of confidence in judges to exercise their right to dissent when the circumstances demand; it is after all, a right and not a duty. However, if that trust exists, the existence of dissents, such as Justice Pal's, allow us to have greater confidence in the integrity of the decision-making process in the majority of cases, where such 'fundamental dissents' are absent. In sum, while Justice Pal's dissent delivered a damaging blow to the credibility of that particular Tribunal and its judgment, it established a precedent — one that operates paradoxically to strengthen the performance legitimacy of the institutions of international criminal justice.

\section{B. 21st Century Judicial Whistleblowing}

More recently, the vehicle of dissent has been used to challenge the exercise of judicial power by judges before the ICC. The self-titled, Minority Opinion, of Judge Van den Wyngaert in the recent Katanga decision provides a clear example of how dissent can be forcefully employed to challenge how the Court uses its power and the impact of the use of that power on the observance of fundamental principles of justice. ${ }^{75}$ The case prompts the validity of fears that fundamental dissents on findings of fact undermine the acceptance of a verdict by the accused and other actors to be questioned. In 2008, the Pre-Trial Chamber confirmed the charges against Germain Katanga of seven counts of war crimes and three counts of crimes against humanity, on the basis of individual criminal responsibility under Article 25(3)(a) of the ICC Statute as co-perpetrator. ${ }^{76}$ These charges related to his alleged role in the 2003 attack against the village of Bogoro in the Ituri District of the Democratic Republic of the Congo, which occurred in the context of the armed conflict occurring between 2002 and 2004. Recharacterizing the mode of liability for those charges from co-perpetration under Article 25(3)(a) to the lesser mode of liability of accessory under Article 25(3)(d), the Trial Chamber proceeded to find Katanga guilty of one count of crimes against humanity and four counts of war crimes as an accessory, acquitting him of all other charges. ${ }^{77}$

Principally, Judge Van den Wyngaert's objection lay in the Trial Chamber's recharacterization of the charges, which she deemed an ultra vires exercise of judicial power vested in the judges by Regulation 55 of the Regulations of the Court. ${ }^{78}$ Agreeing with the Chamber's conclusion that the defendant was not guilty of the charges confirmed by the PreTrial Chamber, and concluding that the decision of the Chamber to re-characterize the charges

\footnotetext{
${ }^{74}$ Totani, supra note 51, at 225-226, noting how Justice Pal stopped attending court proceedings in order to enable him to prepare his dissenting judgment, despite the trial having not been concluded.

${ }^{75}$ Minority Opinion of Judge Van den Wyngaert. Note the language of ICCSt., which refers not to 'dissenting' and 'separate' opinions, but rather that the decision of a trial chamber should 'contain the views of the majority and minority'. See Art. 74(5) ICCSt. Contrast with Art. 83(4) ICCSt., concerning judgments handed down by the Appeals Chamber.

${ }^{76}$ Decision on the confirmation of charges, Katanga and Chui (ICC-01/04-01/07-717), Pre-Trial Chamber I, 30 September 2008.

${ }_{77}^{7}$ Jugement rendu en application de l'article 74 du Statut, Katanga (ICC-01/04-01/07-3436), Trial Chamber II, 8 March 2014.

${ }^{78}$ Minority Opinion of Judge Van den Wyngaert, §§ 16-49.
} 
was 'invalid as a matter of law', ${ }^{79}$ Judge Van den Wyngaert would have acquitted the defendant of all charges. The opinion continued to identify a potential litany of defects in the procedure and infringements of the fundamental rights of the accused as a result of this recharacterization and the manner in which it was conducted. ${ }^{80}$ Judge Van den Wyngaert concluded that their cumulative effect was to present 'a case of overwhelming strength against the legality and legitimacy of this judgment'. ${ }^{81}$ Moreover, even accepting in principle the power of the Trial Chamber to re-characterize the charges, her analysis of the facts led her to the conclusion that the re-characterized charges were not supported in fact, at least by those facts presented to the Chamber by the prosecution and accepted by the Pre-Trial Chamber as forming the basis of the confirmed charges. ${ }^{82}$ An archetypal example of a fundamentally dissenting opinion - Judge Van den Wyngaert made the depth of her disagreement with the Chamber's decision clear in no uncertain term. ${ }^{83}$ This dissent prompted an equally robust response to some of her allegations by the two judges composing the majority. A joint Concurring Opinion in defence of the Chamber's decision was handed down thereafter. ${ }^{84}$

For the purposes of this article, the Katanga decision and accompanying opinions provide a rich contribution to analysis of the functions and effects of judicial dissent and the need for accountability for the exercise of judicial power to vindicate the ICC's performance legitimacy. In particular, taken together, Judge Van den Wyngaert's opinion and Judges Fatoumata Diarra's and Bruno Cotte's joint opinion, are a vivid demonstration of the accountability function of dissent in operation, with the force of the former compelling the latter. At the same time, the failure of the majority judges to respond in the judgment to the concerns expressed by Judge Van den Wyngaert, and by doing so, to strengthen the judgment against the challenge posed by the Minority Opinion was a missed opportunity. One of the traditional justifications for the publication of additional opinions is that the circulation of a draft dissenting opinion prior to the delivery of a judgment enables majority judges to improve the judgment by pre-empting criticisms contained in the dissent. ${ }^{85}$ That the Minority Opinion was responded to by a separate opinion rather than by a strengthened judgment may not stand in support of criticisms of the publication of additional opinions per se, but may be symptomatic of underlying issues (perhaps a breakdown in procedure, or collegiality) and in turn, their causes, that warrant remedial action.

Had Katanga appealed his conviction by the Trial Chamber and relied on reasoning contained in the dissent, this situation would have been the paradigmatic example of how dissent is a mechanism by which the rights of the accused can be vindicated. However, the decision by the accused to withdraw from appellate proceedings and accept the findings of the Trial Chamber, ${ }^{86}$ notwithstanding the gravity of the concerns expressed in the dissent and the force with which they were expressed, gives rise to two questions. Interviews with the

\footnotetext{
${ }^{79}$ Ibid., § 12 .

${ }^{80}$ Ibid., $\S \S 12-14,50-132$.

${ }^{81}$ Ibid., $\$ 15$.

${ }^{82}$ Ibid., $\S \S 3-6,133-308$.

${ }^{83}$ Including, but not limited to, ibid., $\S \$ 1,4,7,85$, and the entire conclusion, $\S \S 309-320$. Jørgensen and Zahar, supra note 2, at 1191-1192.

${ }^{84}$ Concurring Opinion of Judges Fatoumata Diarra and Bruno Cotte, Jugement rendu en application de l'article 74 du Statut, Katanga (ICC-01/04-01/07-3436), Trial Chamber II, 8 March 2014.

${ }^{85}$ R. Bader Ginsburg, 'Remarks on Writing Separately', 65 Washington Law Review (1990) 133, at 143; R.J. Traynor, 'Some Open Questions on the Work of State Appellate Courts', 24 University Chicago Law Review (1957) 211, at 218-223; W.J. Brennan, 'In Defense of Dissents', 37 Hastings Law Journal (1985) 427, at 430; S.H. Fuld, 'The Voices of Dissent', 62 Columbia Law Review (1962) 923, at 927.

${ }^{86}$ Defence Notice of Discontinuance of Appeal against the 'Judgement rendu en application de l'article $74 \mathrm{du}$ Statut' rendered by Trial Chamber II on 7 April 2014, Katanga (ICC-01/04-01/07-3497), Defence for Germain Katanga, 25 June 2014.
} 
accused's defence counsel following the decision to withdraw appellate proceedings show that decision-making by parties to judicial proceedings is influenced by a range of interests and priorities, which may not coincide with those embodied in the ideals of justice as embodied through criminal adjudication. ${ }^{87}$ The decision to accept the verdict of the ICC may be influenced by the perceived correctness of the Court's factual findings, but it is also affected by other factors, including the accused's need for certainty and to obtain closure of proceedings. ${ }^{88}$ In this context, is fundamental dissent on questions of fact as threatening as those opposed to their publication suggest?

In turn, if that anticipated threat is not realized, then this begs the question for advocates for the publication of dissent on questions of fact. If dissent on questions of fact does not prompt litigants to challenge the correctness of a Trial Chamber's verdict through appellate proceedings, then how strong is the argument that it strengthens the ability of the process of justice as a whole to arrive at correct and just outcomes? Whether the result of appellant proceedings would have been to affirm the conviction and reject the merits of the complaints of the accused and concerns of Judge Van den Wyngaert, or whether the Appeals Chamber found merit in those complaints and acted on them, the outcome would have been to strengthen the integrity of the proceedings and conclusion as a whole by addressing those serious concerns.

While it is the right of the accused not to avail himself of the right to appeal the conviction, the failure of the Appeals Chamber to authoritatively address the concerns expressed by Judge Van den Wyngaert risks the possibility that the conviction by the Trial Chamber will remain tainted by those allegations of impropriety. This latter point moves the issue beyond the immediate disputants and brings into focus the public authority exercised by international criminal judges and the wider societal functions of international criminal adjudication. Justice must not only be done, but be seen to be done - not only for the parties to the dispute, but also the wider constituencies with an interest in the proceedings.

In response, it may be considered that from this wider perspective, while the dissenting opinion did not prompt further litigation in the same case, its publication may influence future cases where similar issues arise. The concerns expressed by the Minority Opinion may inform judicial practice in regards to the use of the impugned Regulation 55 power to address those concerns in order to avoid a similarly critical dissent from within the Court. It might equally inform defence pleadings in a case where the accused is subject to the exercise of the Regulation 55 power by the Trial Chamber. Therefore, it would be too early to reject the utility of the Minority Opinion or assume that it vindicates critics' concerns over permitting the publication of (fundamental) dissent.

The Katanga decision and accompanying opinions are instructive for a further reason. Judge Van den Wyngaert's analytical exposition of the evidence presented by the Court - as with Justice Pal's dissent at Tokyo - offers an alternative narrative of the violence forming the heart of the charged crimes, but also the role of the accused in that narrative. At the core of the Minority Opinion is the inextricable link between the charges and factual narrative. As explained by Judge Van den Wyngaert, 'charges allege the existence of specific relations between different facts and construct a particular narrative on this basis which, if true, would cover all the legal elements of the charges with which it corresponds' ${ }^{89}$ Put differently, she continues, 'it would, in theory, be possible to combine the individual pieces that are contained

\footnotetext{
${ }^{87}$ B. Dürr, 'Why the Militia Leader said Sorry: "Tired of the Court"', ICC Observer: Blog, 26 June 2014, available online at http://en.iccobserver.com/2014/06/militia-leader-said-sorry-tired-court (visited 13 March 2015).

${ }^{88}$ Ibid.

${ }^{89}$ Minority Opinion of Judge Van den Wyngaert, § 32.
} 
in the narrative in many different ways'. ${ }^{90}$ Further, as was argued in the dissent, the judgment offers another alternative factual narrative to that presented by the prosecution. ${ }^{91}$

Therefore, once again, the dissent stands as an explicit challenge to how a single judgment on the responsibility of a particular individual in regards to specifically charged crimes is viewed as contributing to the construction or consolidation of a wider historical or factual narrative. Indeed, recalling the legitimation function of war crimes trials referred to in the context of the Tokyo trial, Judge Van den Wyngaert expresses concern over how the Trial Chamber's focus on one aspect of the case - ethnic animosity - not only oversimplifies the conflict and violence forming the subject matter of the case, but 'grossly misrepresents reality, which is far more complex', and further, 'implicitly absolves others from responsibility'. ${ }^{92}$ Judge Van den Wyngaert's dissent supports the view that if the jurisprudence of international criminal courts and tribunals, as a whole, has a pedagogical utility, for individual opinions also suffer the same narrative limitations as the judgment or the case developed by the prosecution, then that utility lies in its contribution to pedagogical enterprises and analysis beyond the courtroom by different actors. Accordingly, in order for the potential that this jurisprudence holds to contribute to such processes to be realized, it is necessary that they are accessible and capable of being effectively disseminated among participants in those processes.

Whereas the priority for the Allied authorities at Tokyo and the Tribunal's Justices may not have been its legacy for a grander normative project of international criminal justice, and while the Katanga dissent begins to raise questions as to the implications of fundamental dissent on the conduct of future cases at the ICC, this precise question of legacy has become a highly contested issue as the ad hoc tribunals draw their two decades of activity to a close. The next section will consider how judicial dissent may be used to preserve the purposive legitimacy of the wider body of law through which international criminal justice is advanced. By undermining the authority of a particular judgment, or even institution, dissent can safeguard the wider interests of international criminal justice.

\section{An 'Appeal to the Brooding Spirit of the Law'?'}

A recent spate of acquittals at the ICTY has brought the issue of dissentient practice to the forefront. This section will focus on the two dissenting opinions to the judgment of the Appeals Chamber in Gotovina and Markač. ${ }^{94}$ The Appeals Chamber reversed the Trial Chamber's finding that the shelling of four Serbian towns in August 1995 during the course of 'Operation Storm' by Croatian forces constituted indiscriminate attacks. This resulted in the acquittal of two Croatian commanders, four counts of crimes against humanity, and four counts of war crimes. ${ }^{95}$ The dissenting judges agreed with the majority that the Court had erred in law in its reliance on the so-called '200 metre standard of review' in order to assess whether the impugned shelling was indiscriminate. ${ }^{96}$ However, unlike the majority, the dissenting judges did not consider this to be fatal to the finding of indiscriminate attacks on

\footnotetext{
${ }^{90}$ Ibid.

${ }^{91}$ Ibid., $\$ \$ 27-49$.

92 Ibid., $\$ 318$.

${ }^{93}$ C. Hughes, The Supreme Court of the United States (Columbia University Press, 1936), at 68.

${ }^{94}$ Judgment, Gotovina and Markač (IT-06-90-A), Appeals Chamber, 16 November 2012.

95 Ibid.

${ }^{96}$ Judge Pocar, § 10-11; Judge Agius, § 2.
} 
the basis of the remaining evidence, and accordingly, would have confirmed the Trial Chamber's conviction of both defendants on all charges. ${ }^{97}$

Quite apart from the challenge that they present to the interpretation of law and evidence in the judgment, the fiery tone of the two dissenting opinions generated a stir within the legal fraternity. Describing the reasoning of the majority in places as 'completely unjustified', 'grotesque', 99 and as 'contradict[ing] any sense of justice', ${ }^{100}$ the dissents forcefully impressed on readers the depth and degree of the disagreement between the judges hearing the appeal. For some, they provided a window to an unsavoury scene of defective process and reasoning lying at the heart of the judgment. ${ }^{101}$ For others, the use of 'inappropriate language' by the judges risked 'damag[ing] the very institution they represent'. ${ }^{102}$

Views on the Appeals Chamber's judgment were just as polarized beyond the courtroom. In Croatia, the reversal of the two convictions in Gotovina and Markač was widely seen as a victory for the nation as a whole. The acquittal of the only two Croats from Croatia to have been prosecuted by the ICTY has been widely seen as validating Croatia's military activities during the course of the conflict, and in particular, Operation Storm. ${ }^{103} \mathrm{In}$ Serbia, in contrast, the acquittal was met with outrage - whereas the judgment reinforced Croatian perceptions of victimhood during the conflicts in the former Yugoslavia - for Serbs it reinforced subsequent Serbian victimhood by the ICTY and the wider international community backing it. ${ }^{104}$ Against this backdrop, and the strength with which attitudes toward the events during the conflict have firmly crystallized on all sides, there was little chance that the two dissenting opinions by Judges Pocar and Agius, however rhetorically powerful, could have tempered those views, at least in the present situation. Time will tell whether there is any scope for these dissents to facilitate debate once the conflict recedes further in the historical memory of the affected societies.

Moving to the jurisprudential legacy, the depth of disagreement between the five eminent and highly experienced judges sitting on the Appeals Chamber gives reason to doubt whether the law in the concerned area is fit for purpose. If one of the fundamental justifications of the rule of law is to imbue certainty in transactions in order to protect legitimate expectations, then the law must be sufficiently certain to enable its subjects to identify the correct law and conduct their behaviour in accordance with the law. The question arises whether the dissenting judges, in order to imbue the law with certainty, should have suppressed or diluted their dissent to create stability, even at the expense of correctness of the law. In other words, should Judges Pocar and Agius have followed the dictum of Justice Louis Dembitz Brandeis, of the US Supreme Court, that 'it is more important that the applicable rule of law be settled than it be settled right'. ${ }^{105}$ It is argued here that given the functions of

\footnotetext{
97 Judge Pocar; Judge Agius.

98 Judge Agius, $\S 26$.

99 Judge Pocar, § 26.

${ }^{100}$ Ibid., $\S 39$.

${ }^{101}$ M. Milanovic, 'The Gotovina Omnishambles', EJIL: Talk! Blog of the European Journal of International Law, 18 November 2012, available online at http://www.ejiltalk.org/the-gotovina-omnishambles/ (visited 13 March 2015).

${ }^{102}$ See, Responsive Comment by M. Zgonec-Rožej, 27 November 2012, in ibid; A. Batesmith, 'Judicial fireworks at the ICTY and the impact of the Gotovina and Markač acquittals', Batesmith Law Blog, 27 November 201, available online at http://www.batesmithlaw.com/1/post/2012/11/-judicial-fireworks-at-the-ictyand-the-impact-of-the-gotovina-and-marka-acquittals.html (visited 13 March 2015).

103 'Hague war court acquits Croat Generals Gotovina and Markac', BBC News, 17 November 2012.

${ }^{104}$ Ibid.

${ }^{105}$ Dissenting Opinion of Justice L. Brandeis, Burnet v. Coronado Oil \& Gas CO. 285 US 393, 406 (1932).
} 
international criminal justice, the dissenting judges in Gotovina and Markač were correct not to have deferred correctness to the objective of stability. In order to do so, the following discussion will critique Judge Mohamed Shahabuddeen's declaration in another case before the ICTY, Orić, where an individual judge favoured stability at the expense of correctness. ${ }^{106}$

In the Orić declaration, Judge Shahabuddeen explained why he had voted to uphold the validity of a point of law stated in the prior decision of the Appeals Chamber in Hadžihasanović and Kubura - a Decision from which he had dissented. ${ }^{107}$ Given that the Chamber in Orić was evenly split over whether to uphold the prior decision on the disputed point of law, ${ }^{108}$ Judge Shahabuddeen's vote was decisive. Concluding his declaration, he explained that a 'decision to reverse [a decision] turns upon more than theoretical correctness: it turns upon larger principles concerning the maintenance of jurisprudence, judicial security and predictability'. ${ }^{109}$ The reasons why these considerations outweighed the reasons he accepted as grounds on which to overturn the prior decision - including the responsibility of the Appeals Chamber to state the correct law, ${ }^{110}$ and its power to correct law - ${ }^{111}$ are not convincingly explained. Further, Judge Shahabuddeen agreed with the dissenting judges in the present case and his continued belief in his minority position in the prior decision. ${ }^{112}$ Nevertheless, Judge Shahabuddeen favoured stability at the expense of correctness.

However, from the perspective of the normative foundations of international criminal justice, this prioritization of stability at the cost of correcting what was widely considered among the judges of the ICTY to be an incorrectly decided point of law is difficult to accept. If the basis for punishment is individual responsibility for the conduct of rational actors, then to be just, the standards according to which that individual's behaviour is judged must be correct. Both the principles of certainty and legality operate on the basis that to conduct their affairs in accordance with the law, rational actors need to know what that law is. But it is submitted that the principle of legality also requires individual behaviour to be judged according to the correct law. For a court to state that the law at a given time was X, and to judge an individual's behaviour according to X, while knowing that the law at that time was actually $\mathrm{Y}$, seems to defeat the objectives underpinning the principles of legality and certainty. While, on the facts of Orić, the disputed point of law was not decisive of the individual responsibility of the accused, ${ }^{113}$ from a systemic perspective this is problematic. As Judge Shahabuddeen observed, ${ }^{114}$ practice suggests that trial chambers of the ICTY are bound to follow the law as stated by the Appeals Chamber. ${ }^{115}$ Therefore, the consequence of his decision to uphold the decision in Hadžihasanović on the disputed point was to bind trial chambers to knowingly apply what was more widely considered to be incorrect law. ${ }^{116}$

More widely, even though international criminal courts and tribunals do not formally possess legislative power, the combined effect of the principles of legality and certainty

\footnotetext{
${ }^{106}$ Judgment, Orić (IT-03-68-A), Appeals Chamber, 4 July 2008, §§ 2-15 (hereinafter 'Orić').

107 Decision on Interlocutory Appeal Challenging Jurisdiction in Relation to Command Responsibility, Hadžihasanović et al. (IT-01-47-AR72), Appeals Chamber, 16 July 2003.

${ }^{108}$ Partially Dissenting Opinion and Declaration of Judge Liu, Orić, §§ 2-28; Separate and Partially Dissenting Opinion of Judge Schomberg, Orić, §§ 1-2.

${ }^{109}$ Declaration of Judge Shahabuddeen, Orić, § 14; Judgment, Aleksovski (IT-95-14/1-A), Appeals Chamber, 24 March 2000, §§ 101-107 (hereinafter 'Aleksovski').

${ }^{110}$ Declaration of Judge Shahabuddeen, Orić, $\$ 12$.

111 Ibid., § 9.

${ }^{112}$ Ibid., $\$ 3$.

113 Ibid., $\$ 9$.

${ }^{114}$ Ibid., $\$ 2$.

115 Aleksovski, § 113.

${ }^{116}$ Declaration of Judge Shahabuddeen, Orić, $\S 12$.
} 
demand that courts must correctly represent the law. Given the semantic authority of courts and tribunals, ${ }^{117}$ rational actors are likely to rely on their pronouncements in order to identify the law according to which they should conduct their behaviour. Therefore, not only should there be a duty on courts to state the correct law, but there should be a duty (rather than simply a power) to correct their statements of the law. Building on observations regarding the contribution of individual opinions at the ad hoc tribunals to the development of an operational body of substantive and procedural international criminal law, ${ }^{118}$ the paradox of dissent, it is argued, operates by ensuring that courts fulfil their duties in respect of the correct law, thereby advancing the interests of justice.

Dissents such as those of Judges Pocar and Agius bring to light the limitations of the legislative power of international criminal courts and tribunals. By creating uncertainty regarding the correctness of statements of the law within a decision of a court, such dissents encourage actors to seek out with certainty whether in fact the decision is a correct reflection of the law. If it is not correct, then actors know not to conduct their behaviour according to it, but if it is, then they can do so with greater confidence. Even when it is concluded that the law articulated by the majority is accurate, dissents, such as those of Judges Pocar and Agius, are appeals 'to the brooding spirit of the law, to the intelligence of a future day' in order to change or reform the law. ${ }^{119}$ Judicial dissent does not merely give representation to the plurality of understanding of those laws, values, and interests that are held by the diversity of actors subject to a universal project of international justice. Rather, the real potential lies in the ability of judicial dissent to contribute to the process of making the project's professed universality real. Judicial dissent within international criminal courts and tribunals forms a platform on which a more diverse range of actors are engaged and empowered in the process of evaluating the weight and contribution of a judgment to the identification of international criminal law.

Accordingly, while the dissents could be appeals to future courts - whether chambers of the ICC or national or hybrid courts - they could equally be appeals to other participants in the process of international lawmaking and law interpretation. Returning to the dispute in Gotovina and Markač, by highlighting the unsatisfactory nature of the application of international criminal law to military decisions relating to matters such as targeting, the judgment and its dissenting opinions have defined the parameters within which the legal and policy debates necessary to clarify this disputed area of law are being conducted. ${ }^{120}$

So far, this article has demonstrated how judicial dissent may be used to constrain the exercise of institutional and semantic authority held by international criminal courts and tribunals. However, the following section argues that judicial dissent may also be a mechanism to hold to account the exercise of prosecutorial power in deciding when the judicial process, and the power it entails, is deployed.

\footnotetext{
${ }^{117}$ Venzke, supra note 38.

118 Sluiter, supra note 2, at 197; Statement of Gabrielle Kirk McDonald, then prosecutor at the ICTY, UN Diplomatic Conference of Plenipotentiaries on the Establishment of an International Criminal Court, Summary Records of the Plenary Meetings and of the Meetings of the Committee of the Whole, Vol. II, UN Doc A/Conf.183/13 (1998), at 79. See also, ICC Plenary Decision, § 51.

${ }^{119}$ Hughes, supra note 93.

${ }^{120}$ See Milanovic, supra note 101; J. Clark, 'Courting Controversy: The ICTY's Acquittal of Croatian Generals Gotovina and Markač', 11 JICJ (2013) 399. For evidence of policy interests, see Application and Proposed Amicus Curiae Brief Concerning the 15 April 2011 Trial Chamber Judgment and Requesting that the Appeals Chamber Reconsider the Findings of Unlawful Artillery Attacks During Operation Storm, Gotovina and Markač (IT-06-90-A), Appeals Chamber, 13 January 2012.
} 


\section{5. 'Judge Gave Hope to Ocampo Four But Chamber Dissented' 121}

The ten year anniversary of the entry into force of the ICC Statute provided an opportune moment for collective reflection on the past, the present, and the future of international criminal justice. ${ }^{122}$ The ad hoc tribunals are drawing their activities to a close and the ICC is established and operational, its Statute ratified by 122 states. Yet, despite the many triumphs for international criminal justice over the past two decades, there is an overwhelming dispirited mood, a loss of momentum, and a sense of uncertainty over where it is going and where it should be going. ${ }^{123}$ This section will examine an instance of judicial dissent at the ICC, which may prompt consideration of what role judicial dissent can, and should, play in the course of these deliberations.

In 2009, the prosecutor of the ICC requested authorization to open an investigation into the situation in Kenya, in light of evidence he had obtained suggesting that crimes within the Court's jurisdiction may have been committed during the violence that followed Kenya's national elections in December 2007. ${ }^{124}$ The request outlined the prosecutor's intention to investigate allegations that acts, including murder, sexual violence, and deportation, constituting crimes against humanity had been committed. ${ }^{125}$ For a period during the pre-trial phase of the investigations by the ICC, one judge - Judge Hans-Peter Kaul - became a focal point for media attention within Kenya. ${ }^{126}$ The reason behind this attention was his dissentient views, repeated in each decision of the Pre-Trial Chamber. ${ }^{127}$ The basic premise of his disagreement lay in his view that the ICC lacked material jurisdiction over the violence, by reason of its failure to satisfy the necessary requirements for it to fall within the definition of crimes against humanity, under Article 7 of the ICC Statute. ${ }^{128}$ By reason of the popular interest generated by this dissenter, Judge Kaul's fundamental message - that while the postelection violence was criminally proscribed conduct, it did not fall within the jurisdiction of ICC — ${ }^{129}$ was repeated consistently and constantly. Consider the fundamental ambition shared by projects of international justice, namely, to delegitimize the politics of violence. ${ }^{130}$ The regular reiteration of Judge Kaul's viewpoint by the media coverage of each of his dissents emphasized within mainstream political discourse the idea that irrespective whether one was 'for' or 'against' the ICC's intervention, the violence committed was not lawful or legitimate.

\footnotetext{
121 'Judge Gave Hope to Ocampo Four but Chamber Dissented', Daily Nation, 26 May 2012.

${ }^{122}$ See the Symposium in 11 JICJ (2013); C. Stahn, "Between "Faith" and "Facts": By What Standards Should We Assess International Criminal Justice?', 25 LJIL (2012) 251; Cassese, supra note 33.

${ }^{123}$ See W.A. Schabas, 'The Banality of International Justice', 11 JICJ (2013) 545; P. Akhavan, 'The Rise and Fall and Rise of International Criminal Justice', 11 JICJ (2013) 527; Stahn, supra note 122, at 252.

${ }^{124}$ Request for Authorisation of an Investigation Pursuant to Article 15, Situation in the Republic of Kenya (ICC01/09-3), Pre-Trial Chamber II, 26 November 2009.

${ }^{125}$ Ibid.

${ }^{126}$ By way of example, see the following headlines from a national Kenyan newspaper: 'Who is this ICC judge who dissented on Kenya?', Daily Nation, 1 April 2010; 'German who has twice differed with other ICC judges', Daily Nation, 9 March 2011; P. Mwaura, 'By Dissenting, Judge Kaul Could Tilt Public Opinion over the Ocampo Six', Daily Nation, 12 March 2011; 'ICC Judge: Why I refused to give summons', Daily Nation, 16 March 2011; 'Judge: Crimes a Kenyan affair', Daily Nation, 16 March 2011; 'Who's who in the Kenya case at the ICC?', Daily Nation, 6 April 2011; 'German Judge Insists suspects should have been tried in Kenya', Daily Nation, 23 January 2012.

${ }^{127}$ See Dissenting Opinion of Judge Kaul, Authorization.

${ }^{128}$ Ibid.

${ }^{129}$ Ibid., § 6.

${ }^{130}$ Shklar, supra note 25.
} 
From the perspective of the project of international criminal justice, Judge Kaul's dissents are intriguing on another level. Before elaborating a detailed explanation of the legal basis of his opinion, he took a moment to explicitly justify it on a policy basis, which he identified as being the 'interest of criminal justice in general and international criminal justice in particular'. ${ }^{131}$ Judge Kaul explicitly addressed how such ICC interventions into some situations may actually hinder the pursuit of the wider objectives of international criminal justice by undermining the ability of the ICC to conduct its activities effectively and efficiently. He explained that the 'gradual downscaling of crimes against humanity towards serious crimes' risked infringing on state sovereignty and opening the ambit of the Court's jurisdiction indefinitely. In turn, he argued that in light of the Court's reliance on state cooperation and its limited financial and material resources and capacity, stretching the Court's capacity further while, at the same time, antagonizing the very states on which it relies for cooperation would undermine the Court's 'standing and credibility'. Crucially, the result of this, he concluded, might be to deprive victims of any access to justice, due to the inability of the Court to conduct investigations into situations. ${ }^{132}$

The legal basis for his opinion - that the ICC lacks jurisdiction over the situation served to undermine the substantive authority of the Court despite the majority having determined that the Court held competence. Might dissents during this phase of proceedings affect cooperation with the Court by affected individuals and states in subsequent stages of proceedings (recall Judge Kaul's observations regarding the ICC's reliance on state cooperation)?

Yet, once more, it is possible to identify the paradox of dissent in operation. Indeed, Judge Kaul explicitly claimed to be using his right to dissent in order to advance international criminal justice. ${ }^{133}$ At the outset of this section, it was observed that international criminal justice is suffering from a loss of confidence. It appears to be struggling to defend its legitimacy against allegations of selectivity and institutional bias, typically against African states and their governing officials, while at the same time, failing to ensure accountability for violations of international criminal law when those accused are officials of powerful states and their allies. ${ }^{134}$ Belying these tensions are concerns that international criminal justice and its institutions, as they operate today, are not giving effect to the values and interests of a considerable section of its constituency, thus calling into question their purposive legitimacy. ${ }^{135}$ In practical terms, as Judge Kaul explained, this affects state cooperation (implying an impact on its consent legitimacy) and the efficacy with which the ICC can pursue its accountability objectives.

As has been discussed throughout this article, the dissenting opinion holds potential to be a visible and powerful platform from which to be heard. The publication of dissent demonstrates that there are voices within the institution that share the views and concerns held within significant sections of the constituencies of international criminal justice. Contrast the potential audience of a dissenting opinion (particularly those concerning highly contentious cases attracting considerable public interest) with the audiences that a judge might expect when writing or speaking extra-judicially, for example, at a conference or in an academic journal. Therefore, as in the case of fundamental dissents on matters of law, could judicial dissent on matters of policy of international criminal justice help to instigate and inform

\footnotetext{
${ }^{131}$ Dissenting Opinion of Judge Kaul, Authorization $\S 10$.

132 Ibid.

${ }^{133}$ Ibid., § 10.

${ }^{134}$ Schabas, supra note 123.

${ }^{135}$ Cassese, supra note 21.
} 
debates among those actors more responsible for decisions on such matters? Should judicial dissent be used to such effect?

\section{Conclusion}

In the United States there exists a political magazine entitled Dissent. ${ }^{136}$ Recently its ethos has been described as 'a spirit of criticism, a vision of a more just society, an openness to movements of democratic change, a refusal to accept the given on its own terms'. ${ }^{137}$ It is further explained how the founder of the magazine envisaged this ethos as one of a modest and humane utopia - 'a yearning for what is not but may be'. ${ }^{138}$ On this view of dissent, perhaps it could be said that the project of international criminal justice — with all the grand objectives attributed to it - is steeped in the ethos of dissent.

Yet, dissenting judges occupy a peculiar position in the process of international justice - at once they stand inside and outside the authority of the court. ${ }^{139}$ Despite their personal disagreement, their contribution to the composition of the chamber as well as their participation in proceedings are constitutive of the formal authority vested in the judgment. By signing the judgment, the dissenting judge accepts both that authority and their own responsibility for that judgment as a member of the chamber. ${ }^{140}$ But, at the same time, their dissent - a product of their voting against one or more of the dispositive paragraphs of the judgment — signals their simultaneous dissociation from that same judgment. It has been argued that, from this position (perhaps in itself, a paradox), dissenting judges serve a critical function in holding to account the exercise of power, judicial (Justice Pal, Judge Van den Wyngaert and Judges Pocar and Agius) and prosecutorial (Judge Kaul).

Looking forward, what does this mean for analysis of dissentient practice? While it may correctly be observed that certain instances of judicial dissent risk undermining the authority of international criminal courts and tribunals and their pronouncements, we should be cautious not to end our analysis there. The very act of, or potential to, undermine institutional authority - and in doing so constrain the exercise of judicial power and its consequences - may serve to strengthen the legitimacy of those same institutions. By strengthening acceptance of those institutions within the constituencies that they serve, in the long term, this paradox of dissent can aid the pursuit of the ambitions of international criminal justice.

\footnotetext{
${ }^{136}$ See Dissent Magazine, available online at http://www.dissentmagazine.org/ (visited 13 March 2015).

${ }^{137}$ G. Packer, 'A Modest Utopia', Daily Comment Blog of The New Yorker, 22 October 2013, available online at $\quad$ http://www.newyorker.com/online/blogs/comment/2013/10/a-modest-utopia-sixty-years-of-dissent.html (visited 13 March 2015).

${ }^{138}$ Ibid.

${ }^{139}$ See A. Nandy, 'The Other Within: The Strange Case of Radhabinod Pal's Judgment on Culpability', 23 New Literary History (1992) 45.

${ }^{140}$ See M. Shahabuddeen, International Criminal Justice at the Yugoslav Tribunal: A Judge's Recollection (Oxford University Press, 2012), at 75.
} 